\title{
Establishing Gender Sensitive Witness and Victim Protection Measures in Complex Criminal Cases
}

\author{
VIVIAN CHUKWUDUMEBI MADU (Mrs) \\ Senior Research Fellow, Department of African and Comparative Law, Nigerian Institute of Advanced Legal Studies.
}

NNENNA JOY EBOH

Research fellow, Nigerian Institute of Advanced Legal Studies, Abuja, Nigeria.

Abstracts

The justice system relies heavily on evidence to establish the commission of a crime. In most complex criminal cases such as human trafficking and terrorism, these evidence are not readily or easily accessible for a number of factors. One of such reason is that most times victims may be dead and so cannot give oral testimony of what happened to them. Another reason is that where the victims or witnesses of complex crimes are children or women, they are usually vulnerable and are over taken with fear of what may happen to them or members of their family if they reveal the truth of what they know. For this reason, it is difficult for them to step out to give evidence to the police not to talk of give oral testimony in the open court of what they witnessed. Where in the cause of an investigation of a crime the police however stumbles on human who witnessed the commission of a crime or is a victim, it is the duty of both the investigator and the prosecutor to protect such vital witness knowing how sensitive and vital their evidence would help to bring about closure on the perpetuators of the crime. This paper identifies the challenges of witnesses and victims of complex crimes (such as terrorism) in supporting the justice system by giving evidence of the commission of a crime without being protected by the State. For this reason the paper proffers solutions on witness protection measures that can be made available to them.

Keywords: Victim, witness, vulnerable witness.

DOI: $10.7176 / \mathrm{JLPG} / 112-11$

Publication date: August 31st 2021

Introduction

In order for the prosecutor in a criminal trial to prove his case before a trial judge, he would be required to adduce evidence. Such evidence has to be tendered as exhibit by a prosecution witness or oral evidence by one who witnessed the commission of the crime. Where the crime is of a simple nature, the witness may not be under threat, however for complex organized crime that involves syndicates, threat may arise not only from the accused person but from members of his gang. It is in order to protect prosecution's witness from these threat that witness protection is very necessary. Witness protection is an indispensable tool in the fight against domestic and international crime.

This is especially because victims and witnesses are the cornerstones for the success of justice and accountability for criminal offences and complex cases such as terrorism offences. Given the nature of these offences, it is important that victims and witnesses who interact with the justice process on these crimes have confidence that their safety and security will be assured. They need to be guaranteed that they will receive support and protection from intimidation and harm that perpetrators or their supporters or others may seek to cause, in order to intimidate, discourage or silence them from testifying. Victim and witness protection measures should aim to substantially reduce the threat and intimidation, even while acknowledging that it cannot guarantee their complete elimination. ${ }^{1}$

From the perspective of victims, right to truth, right to closure and right to effective remedy are important rationale for protection. Victim and witness protection is an essential component of efforts to investigate and prosecute complex criminal cases such as human trafficking and terrorism related offences. ${ }^{2}$ A successful victim and witness protection programme compliments and facilitates efficient investigations and prosecutions of perpetrators of terrorism. State responsibility includes ensuring protective measures are in place for victims and witnesses who engage with justice and accountability processes for gross violations of human rights. ${ }^{3}$ Support and protection measures should take fully into account the individual situation and needs of the witnesses, including gender and other variabilities such as age and disability, as well as the nature of the crime. ${ }^{4}$

Although witness protection is not cheap, the costs are reasonable compared to labour intensive investigative measures such as infiltration or long-term surveillance. ${ }^{5}$ For this reason, evidence shows that witness protection is more effective and efficient than those other methods, especially in cases of terrorism.

${ }^{1}$ United Nations Office on Drugs and Crime (UNODC) Handbook on effective prosecution responses to violence against women and girls, available on http://www.unodc.org/documents/justice-and-prisonreform/Handbook on effective prosecution responses to violence against women and girls.pdf. Accessed on $18^{\text {th }}$ July, 2021.

${ }^{2}$ UNODC Victim Assistance and Witness Protection, available on

$<$ https://www.unodc.org/unodc/en/organized-crime/witness-protection.html $>$ Accessed $23^{\text {rd }}$ June 2020.

${ }^{3}$ Report on Witness Protection (Best Practice Survey); Adopted by Committee PC-CO at its 3rd plenary meeting (Strasbourg, $15-17$ February 1999) at pg. 11-12.

Available on https://www.coe.int/t/dg1/legalcooperation/economiccrime/organisedcrime/BestPractice1E.pdf, accessed on $18^{\text {th }}$ July, 2021.

${ }^{4}$ UNODC (2008) Good practices for the protection of witnesses in criminal proceedings involving organized crime, 19. Available on www.unodc.org/documents/southeastasiaandpacific//Publications/Projects/indonesia/Good_practices for_the_protection_of_witnesses_in_criminal_proceedings_involving_organized_crime.pdf, (Accessed $23^{\text {rd } J u n e ~ 2020) . ~}$

${ }^{5}$ Physical surveillance is one of the oldest law enforcement investigative tools. If authorities suspect someone is engaging in illicit activities, such a person is followed. While this is a widely used investigative tool, some countries have limitations to physical surveillance especially because it negates the right to privacy. Electronic surveillance is similar particularly for undercover operations as it allows for the collection of a broader range of evidence. It is a preferred investigative method "when an organized criminal group cannot be penetrated by an outsider, or where physical infiltration or surveillance would represent an unacceptable risk to the investigation or to the safety of investigators". See "Physical and electronic 
This paper is divided into five parts. The first part introduces the subject matter as well as clarifies concepts used in the paper. The second part discusses the legal framework of witness protection measures used during criminal proceedings at the international and national levels This is followed by the third part which highlights some criminal cases in Nigeria where protective measures have been used and the extent to which these protective measures were used. The forth part focuses on gender sensitive witness protection measures. The paper concludes with recommendation and conclusion in the fifth part.

\subsection{Literature review}

According to Waziri, ${ }^{2}$ Witness Protection Programme is not well developed in Nigeria. Victims and witnesses are usually reluctant to give information and evidence in court because of perceived or actual fear, intimidation or threat against their life or that of their family members. ${ }^{3}$

It is on this ground that Ban Ki Moon is quoted to have said that

"...it is for the sake of humanity that we must create a global forum for your voice and listen to you, the

victims... You deserve social recognition, respect and dignity... ${ }^{4}$

Thus, we agree that according respect and dignity to the victim and witness in a criminal case will include attaching some level of protection to their existence. It is for this reason that $\mathrm{Welsh}^{5}$ recommends the use of close circuit television for the purpose of obtaining the evidence of witnesses in complex criminal cases, while maintaining confidentiality. Eniko ${ }^{6}$ stresses the importance of the protection of witnesses. As George $^{7}$ puts it witness protection is an integral part of the prosecution of complex crime. Graham ${ }^{8}$ on his part suggested specific ways to preserve trustworthy out of court statements for the purpose of admitting them as substantive evidence in court. Especially were the witness is afraid of giving oral testimony in court.

\subsection{Concept Clarification}

1.2.1 Victim

A victim is an individual who may have suffered as a result of a crime or individuals who suffered indirectly, such as the immediate family or dependents of the direct victim and any other person who have suffered harm as a result of intervening to assist direct victims. ${ }^{9}$ This means that a victim may either be a direct or an indirect victim. In the context of terrorism for instance, direct victims suffer violations of their human rights by terrorist groups including abduction, enslavement, and sexual and gender-based violence (SGBV) such as rapes, forced marriages, and sexual slavery. Indirect victims may suffer internal displacement or the loss of financial stability.

\subsubsection{Witness}

A person, including a victim of a gross human rights violation or serious violations of humanitarian law, who possesses information relevant to a justice and accountability process and who, either has agreed to testify or who has been contacted by the parties in the proceedings with the aim of obtaining the information they possess. ${ }^{10}$ It includes experts. According to a publication by United Nations Office on Drugs and Crime (UNODC), a witness is a person with information that is crucial to judicial proceedings, including criminal proceedings. ${ }^{11}$ However,

surveillance', E4J University Module Series: Organized Crime, Module 8: Law Enforcement Tools and Cooperation, available on https://www.unodc.org/e4j/en/organized-crime/module-8/key-issues/special-investigative-techniques/physicaland-electronic-surveillance.html, accessed on $18^{\text {th }}$ July, 2021.

${ }^{1}$ See Report on Witness Protection (Best Practice Survey), Ibid.

${ }^{2}$ Fatima Waziri-Azi, Legal Framework of Witness Protection Measures during Criminal Trial in Nigeria and Emerging Practices, European Journal of Research in Social Sciences Vol. 7 No. 1, 2019 ISSN 2056-5429 Progressive Academic Publishing, UK Page 3 www.idpublications.org

${ }^{3}$ The Office of the United Nations High Commissioner for Human Rights, commonly known as the Office of the High Commissioner for Human Rights (OHCHR) tool on Witness and Victim Protection,

$<$ https://www.ohchr.org/Documents/Publications/Chapter14-56pp.pdf $>$.

${ }^{4}$ Excerpt from the speech of the former secretary of the United Nations during the United Nations Secretary-General's Symposium on Supporting Victims of Terrorism, 9 September, 2008 quoted in The Criminal Justice Response to support Victims of Acts of Terrorism available on http://www.un.org/en/terrorism/ctitf/pdfs/victims rights_e-book- accessed on $18^{\text {th }}$ July, 2021.

${ }^{5}$ Welsh, Brandon C., and David P. Farrington. "Effects of Closed-Circuit Television on Crime." The Annals of the American Academy of Political and Social Science, vol. 587, 2003, pp. 110-135. JSTOR, www.jstor.org/stable/1049950. Accessed 19 July 2021.

${ }^{6}$ Eniko F, The rising importance on the protection of witness https://www.caim.info.revue-internationale-de-droit, accessed on $21^{\text {st July } 2021 .}$

${ }^{7}$ George, B. J. "Victim and Witness Protection," Contemporary Federal Criminal Practice, (1984) Vol. 2, p. 683

${ }^{8}$ Graham, M.H, Witness Intimidation-The Law's Response, Quorum Books, Division of Greenwood Press, Inc, (1985). P. 330

${ }^{9}$ This definition was adopted by the United Nations Declaration (1985), also known as Declaration of Basic Principles of Justice For Victims of Crime and Abuse of Power in recognition of the importance of setting minimum standards in the delivery of justice for victims. See 'Understanding the concept of victims of crime and a short history of victimology', E4J University Module Series: Crime Prevention and Criminal Justice

Module 11: Access to Justice for Victims, available on https://www.unodc.org/e4j/en/crime-prevention-criminaljustice/module-11/key-issues/1--understanding-the-concept-of-victims-of-crime.html, accessed on 18 ${ }^{\text {th }}$ July, 2021.

${ }^{10}$ See Basic Principles and Guidelines on the Right to a Remedy and Reparation for Victims of Gross Violations of International Human Rights Law and Serious Violations of International Humanitarian Law Adopted and proclaimed by General Assembly resolution 60/147 of 16 December 2005, available on https://www.ohchr.org/en/professionalinterest/pages/remedyandreparation.aspx, accessed on $19^{\text {th }}$ July, 2021

${ }^{11}$ Ibid. 
there are three types of witnesses who may require protection and they include justice collaborator, victim-witnesses and other types of witnesses like innocent bystanders, expert witnesses and others. ${ }^{1}$

\subsubsection{Vulnerable witness}

Vulnerable witnesses are witnesses and victims who are at increased risk to be psychologically harmed by testifying and/or who may face psychological or physical difficulties by testifying. ${ }^{2}$ Vulnerability can be determined by various parameters such as age, disability, personality, the nature of the crime a victim suffered from, previous experiences, coping skills and other psychosocial factors. These factors influence witnesses' capacity to give an accurate statement, deal with the stress of testifying, be confronted with the accused or cope with cross-examination.

\section{International Framework and Standards on Witness Protection}

States have a responsibility to respect the fundamental rights of victims, assist them in accordance with their special needs, and protect them from further harm. Therefore all criminal justice systems have a duty to put in place procedures to provide measures for the protection of persons whose cooperation with the criminal justice system in an investigation or prosecution puts them, or persons closely associated with them, at risk of serious physical or emotional harm.

Such protective measures include-

a. Assistance before and during trial to cope with the psychological and practical obstacles of testifying;

b. Protective measures before, during and after hearing or trial for "at risk" witnesses;

c. Court procedures to ensure the witness safety while testifying, and

d. A convert witness protection programme.

Some international victim and witness protection measures in criminal proceedings include-

\subsection{United Nations Convention against Transnational Organized Crime (UNTOC)}

Article 24 of the United Nations Convention against Transnational Organized Crime (UNTOC) ${ }^{4}$ calls for States Parties to take appropriate measures to provide effective protection from retaliation or intimidation of witnesses who give testimony in cases involving transnationa organized crime. The measures envisaged include physical protection, the relocation and non-disclosure or limitations on the disclosure of the identity and whereabouts of the witness and the introduction of evidentiary rules to permit testimony to be given in a manner that ensures the witness's safety. States parties are to consider entering into agreements or arrangements with other States for the relocation of witnesses. ${ }^{5}$ The provisions of the article apply also to victims insofar as they are witnesses. ${ }^{6}$ The protection of victims and/or witnesses is also explicitly addressed in the protocols to the United Nations Convention against Transnational Organized Crime. ${ }^{7}$

\subsection{International Tribunals Witness Protection Programme}

The role of victims in International Criminal Court proceedings compliments the efforts undertaken by the court to hold accountable individuals who are responsible for the most serious crimes which are of concern to the international community. The principle behind this is that true justice is achieved when voices of victims are heard and their sufferings addressed. In view of the foregoing, witness protection has been granted high profile practice and jurisprudence of international tribunals dealing with serious violations of humanitarian law. Hence the statutes of the international Criminal Tribunal for the former Yugoslavia (ICTY), the International Criminal Tribunal for Rwanda (ICTR), the International Criminal Court (ICC), the Special Courts of Sierra Leone (SCSL), and the Extraordinary Chambers in the Courts of Cambodia (ECCC), all provide for setting up witness and victim support units. ${ }^{8}$

Specifically, Article 22 and 21 of the ICTY and ICTR, respectively state that the International Tribunal shall provide in its rules of procedure and evidence for the protection of victims and witnesses. Such protection measures shall include, but not limited to the conduct of in camera proceedings and the protection of the victim's identity. ${ }^{9}$

Article 16(4) of the Statute of SCSL provides that: the Registrar shall set up a Victims and Witness Unit within the Registry. This Unit shall provide, in consultation with the office of the Prosecutor, protective measures and security arrangements, counseling and other appropriate assistance for witnesses, victims who appear before the court and others who are at risk on account of testimony given by such witnesses. The Unit personnel shall include experts in trauma, including trauma related to crimes of sexual violence and violence against children.

2.3 Witness Protection Programme in Nigeria

\footnotetext{
${ }^{1}$ Ibid.

${ }^{2}$ See International Criminal Court: "Protocol on the vulnerability assessment and support procedure used to facilitate the testimony of vulnerable witnesses" (ICC-01/05-01/08-974-Anx2), available on https://www.icccpi.int/RelatedRecords/CR2014 10208.PDF, accessed on $19^{\text {th }}$ July, 2021. The Introduction part of this protocol describes the vulnerability assessment and support procedure used to facilitate the testimony of vulnerable witnesses. The protocol is a part of the measures the Victims and Witnesses Unit ("VWU") put in place to protect the psychological well-being, dignity and privacy of witnesses and in particular those who are at increased risk of psychological harm through the process of testimony. ${ }^{3}$ Ibid. The use of a broad definition of vulnerability avoids stigmatisation of specific groups and acknowledges the fact that any witness may be vulnerable. At the same time it ensures that groups of victims with an increased risk of vulnerability, such as victims of gender-based violence or child witnesses, receive the appropriate attention and support to which they are entitled.

${ }^{4}$ General Assembly resolution 55/25, annex I.

${ }^{5}$ Para. 3.

${ }^{6}$ Para. 4.

${ }^{7}$ Specifically in the Protocol to Prevent, Suppress and Punish Trafficking in Persons, Especially Women and Children, supplementing the United Nations Convention against Transnational Organized Crime (General Assembly resolution 55/25, annex II, articles 6 and 7) and the Protocol against the Smuggling of Migrants by Land, Sea and Air, supplementing the United Nations Convention against Transnational Organized Crime (Assembly resolution 55/25, annex III, articles 5 and 16).

${ }^{8}$ Available on https://www.unodc.org/unodc/en/organizedcrime/witness-protection.html at page 21, accessed $23^{\text {rd }}$ June 2020.

${ }^{9}$ Ibid.
} 
In Nigeria witness protection programme is still undergoing development. There are some domestic legislations such as the NAPTIP Act, the Terrorism Prevention Act (TPA)/Terrorism Prevention Amendment Act (TPAA) and the Administration of Criminal Justice Act which make provisions for Witness Protection.

2.4 National Agency for Protection of Traffic in Person Protection of Victims in Nigeria

The National Agency for Prohibition of Traffic in Persons (NAPTIP) has been able to offer victims full protection against physical violence from agents of trafficking and this includes victims who have testified against traffickers abroad or in Nigeria or are indebted to their agents or madams.

NAPTIP has put up protective programmes/measures to effectively protect victims of human trafficking in Nigeria. This is possible through enough funding by the Nigerian government. Under the programme the personal history and information on a trafficked or exploited victim shall remain confidential and is entitled to give evidence in court against his/her trafficker in camera. As a victim you have access to the embassy or consulate of your country, and that victim is entitled to institute civil action against his/her trafficker or any other person who have exploited or abused him/her, and that the person and identity of a victim shall be protected against any likely attack from his/her trafficker or his associates. In addition to the foregoing NAPTIP have established shelters to cater for the reintegration and rehabilitation of trafficked victims in Abuja, Lagos, Kano, Edo, Enugu Sokoto, and Akwa-ibom states. The active shelters have first aid capacity, a visiting medical director and referral capacity to hospitals. NAPTIP is able to assist any victim that is deported back to Nigeria who is willing to cooperate with them by giving information through investigation and trial of a trafficker.

\subsection{Terrorism (Prevention) (Amendment) Act 2013}

This Act amends the Terrorism (Prevention) Act No. 10 of 2011. The Act makes provisions for the protection of informants and witnesses. Session 33 of the Act $^{1}$ provides that where a person volunteers to the relevant law enforcement or security agency any information that may be useful in the investigation or prosecution of an offence, the agency shall take all reasonable measures to protect the identity and life of that person and the information so volunteered shall be treated as confidential. Section $34(1)^{2}$ further provides that the court may on its own or on a motion by the Attorney-General or a relevant law enforcement or security agency, protect a witness or any person in any proceeding before it where it is satisfied that the life of the person or witness is in danger. The court will equally take measures as it deems fit to keep the identity and address of the witness or person secret. Section $34(2)^{3}$ provides that the measures which the court may take under sub section (1) may include;

a. Holding of the proceedings at a place to be decided by the court;

b. Avoidance of the mention of the real name and address of the witness or person in its orders, judgments or records of the case, which are accessible to the public; or

c. Issuing of a direction for ensuring that the identity and address of the witness or person are not disclosed

d. Undertaking the proceeding in camera in order to protect the identity and location of witnesses and other persons.

Section $34(3){ }^{4}$ provides that the court may also decide, in the public interest and national security that all or any of the proceedings pending before the court shall not be published in any manner. Such proceedings shall be adjourned and the accused persons detained pending when the Attorney-General is able to guarantee the safety of the witnesses and other persons involved in the matter. Section $34(4)^{5}$ provides that the court may, on an application by or on behalf of the relevant law enforcement or security agency, in the interest of public safety or order, exclude from proceedings for any offence under this Act any person other than the parties and their representatives.

Section $34(5)^{6}$ provides that a person who contravenes an order or direction made under this section commits an offence and is liable on conviction to imprisonment for a term not less than 5years.

\subsection{Administration of Criminal Justice Act (ACJA) 2015}

This Act under section $232^{7}$ provides for witness protection in Nigeria. Section $232(2)^{8}$ provides that names, addresses, telephone numbers and identity of the victims of such offences or witnesses shall not be disclosed in any record or report of the proceedings and it shall be sufficient to designate the names of the victims or witnesses with a combination of alphabets. Section $232(3)^{9}$ provides that where in any proceeding the court deems it necessary to protect the identity of the victim or a witness, the court may take any or all of the following measures.

a. receive evidence by video link;

b. permit the witness to be screened or masked;

c. receive written deposition of expert evidence; and

d. any other measure that the court considers appropriate in the circumstance.

Section 232 (4), ${ }^{10}$ provides that the provisions of the section shall apply to:

a. offences under the Terrorism(Prevention) Amendment Act;

b. offences relating to Economic and Financial Crimes;

c. offences under section 231 of this Act;

d. trafficking in Persons and related offences; and

e. any other offences in respect of which an Act of the National Assembly permits the use of such protective measures or as the Judge may consider appropriate in the circumstances.

Section $232(5)^{11}$ provides that any contravention of the provisions of subsection (2) of this section shall be an offence and liable on conviction to a minimum term of one year imprisonment.

\footnotetext{
${ }^{1}$ Terrorism (Prevention) (Amendment) Act 2013.

2Ibid, Section 34 (1).

${ }^{3}$ Terrorism (Prevention) (Amendment) Act 2013, Section 34 (2).

${ }^{4}$ Ibid, Section $34(3)$

${ }^{5}$ Ibid, Section 34 (4).

${ }^{6}$ Ibid, Section 34 (5)

${ }^{7}$ Administration of Criminal Justice Act (ACJA) 2015, Section 232.

${ }^{8}$ Ibid, Section 232 (2).

${ }^{9}$ Section 232 (3) Administration of Criminal Justice Act (ACJA) 2015.

${ }^{10}$ Section 232 (4) Administration of Criminal Justice Act (ACJA) 2015.

${ }^{11}$ Section 232 (5) Administration of Criminal Justice Act (ACJA) 2015.
} 


\section{Criminal cases on Victim protection in Nigeria}

\section{$3.1 \quad$ Federal Republic of Nigeria v Nnamdi Kanu \& ors}

In the case of Federal Republic of Nigeria v. Nnamdi Kanu \& ors ${ }^{l}$, the first defendant was the Director of Radio Biafra and Television. He and his cohorts were alleged to have committed treasonable felony, an offence punishable under section 41(1) of the Criminal Code Act Cap. C38 Laws of the Federation. Kanu was alleged to have illegally smuggled radio transmitters into Nigeria which he used to 'disseminate hate broadcasts' encouraging the "secession of the Republic of Biafra from Nigeria." The Federal High Court sitting in Abuja upheld the Federal Government's application to screen witnesses/shield witnesses who will testify against the leader of the Indigenous people of Biafra (IPOB) Nnamdi Kanu. This decision of court was aimed at protecting the identity of the witnesses.

\subsection{Kabiru Umar v. Federal Government}

In the case of Kabiru Umar v. Federal Government ${ }^{2}$, Kabiru Umar was charged for bombing St Theresa's Catholic Church, Madalla, Niger State on 25 December 2011 that killed about forty- five persons and wounded seventy-five others. ${ }^{3}$ During his trial on a three-count charge at the Federal High Court, Abuja Division, the court employed identity-protecting measures including the use of masks and pseudonyms to refer to witnesses, and also excluded the public from court. Kabiru was convicted of terrorism and handed a life sentence on December 20 th, 2013. In Aminu Ogwuche v. Federal Government, ${ }^{4}$ Aminu Ogwuche was charged on a two-count charge for allegedly bombing a crowded motor park at Nyanya, Abuja on April 14 2014. Bomb blast killed over seventy-five people and wounded one hundred others. ${ }^{5}$ In contrast to Kabiru Umar's case, the judge did not allow witnesses to wear masks due to opposition from the defense. Prosecutors were instead allowed to make use of pseudonyms and camera testimony. The judge in this matter struck out the charges against Aminu Oguche, based on lack of "diligent prosecution by the state. ${ }^{6}$ In the case of Mohammed Nazeef Yunus v. Federal Government, ${ }^{7}$ Mohammed, a university lecturer, spiritual leader and recruitment coordinator of a terrorist cell in Kogi State was charged in 2013 for allegedly planning to carry out terroris attacks in Kogi State. ${ }^{8}$ Mohammed reportedly refused to testify given the judge's ruling against wearing masks during trial. ${ }^{9}$ The judge in this case also ruled against excluding the public from court, rather, opted for cubicles to be used to shield the witness from public viewing. The trial is still ongoing.

\section{Sambo Dasuki v. Federal Government}

Sambo Dasuki v. Federal Government, ${ }^{10}$ in 2017, the Federal High Court, Abuja division, allowed witnesses to testify behind a screen, protecting them from the public.

4. Gender sensitive witness protection mechanisms

Almost all witnesses and victims suffer from some degree of stress during or after their involvement in investigations and prosecutions of terrorism cases. The stress is mostly caused by the formal nature and particular demands of the proceedings, unfamiliar to most witnesses and victims, and by the importance of the process. More importantly, the majority of witnesses and victims testify about events that had a significantly negative and often-traumatic impact on their lives, their communities and societies and or because they have lost loved ones, were injured or lost their place in the community. Others were eyewitnesses of horrific events. All these witnesses require some form of support and assistance to be able to testify truthfully. For some of them, it is sufficient to provide information on how the process works. Some other witnesses, especially women and children, however are in need of extensive assistance and support throughout their involvement in the justice process, because of their increased vulnerability. Additional considerations need to be taken into account when interviewing female suspects who may themselves have been victims of sexual violence or trafficking in persons, making it more difficult and/or dangerous for them to cooperate with terrorism investigations. In such circumstances, although the interviewer may be dealing with a suspect, care must be taken to avoid re-victimization. ${ }^{11}$

The growing crimes against women by terror groups mean that there needs to be specialised interventions to assist women to go through the very difficult task to testify about their ordeal. In order to successfully engage women victims in particular victims of sexual violence in the justice processes, it is critically important that their particular needs and rights including mental health are properly reflected in national legal frameworks. A number of international instruments have developed guidelines on protection of witnesses in judicial processes. The

${ }^{1} \mathrm{FHC} / \mathrm{ABJ} / \mathrm{CR} / 383 / 2015$

2 (2013) Unreported. Accessed [Online] at: https://www.vanguardngr.com/2013/12/catholicchurch-bombing-courtsentenceskabiru-sokoto-life-imprisonment/

3 Available on https://www.vanguardngr.com/2013/12/catholicchurch-bombing-court-sentences-kabiru-sokoto-lifeimprisonment/, accessed $23^{\text {rd }}$ June 2020.

${ }^{4}$ (ECW/CCJ/APP/09/15) [2018] ECOWASCJ 2.

5 Available on https://www.vanguardngr.com/2015/07/nyanyabombing-court-dismisses-ogwuches-n600m-suit-against-fg/, accessed $23^{\text {rd }}$ June 2020.

${ }^{6}$ Available on https://www.premiumtimesng.com/news/headlines/171825-alleged-nyanya-bomber-clearedcourt.html, accessed 23rd June 2020.

${ }^{7}$ Unreported. Accessed on https://www.thenigerianvoice.com/news/145208/boko-haram-fg-wants-court-to-allow-maskedwitnesses.html

8 Available on https://www.dailytrust.com.ng/news/general/sssparades-lecturer-four-others-as-boko-haramsuspects/32720.html, accessed 23rd June 2020

${ }^{9}$ Available from the World Wide Web: http://www.punchng.com/news/bharam-witnessrefuses-to-testify-in-open-court/, accessed $23^{\text {rd }}$ June 2020.

${ }^{10}$ SC. $617 / 2016$ \& SC.618/2016

11 See generally, An Introduction to Human Trafficking: Vulnerability, Impact and Action, available on https://www.unodc.org/documents/human-trafficking/An_Introduction to_Human_Trafficking__ Background_Paper.pdf,

Nigeria Training Module on Gender Dimensions of Criminal Justice Responses to Terrorism, available on https://www.unodc.org/pdf/terrorism/Web_stories/UNODC_Nigeria_Gender_Training_Module.pdf, Investigating Human Trafficking Cases Using a Victim-centred Approach: A Trainer's Manual on Combating Trafficking in Persons for Capacitybuilding of Law Enforcement Officers in Antigua and Barbuda, Belize, Jamaica, and Trinidad and Tobago, available on https://publications.iom.int/system/files/pdf/investigating_human trafficking.pdf, 
framework of key instruments such as the Convention on the Rights of the Child (CRC) and the Convention on the Elimination of all forms of Discrimination against women (CEDAW) ${ }^{1}$ have addressed the needs of specific groups of vulnerable witnesses and victims, mostly victims of specific crimes, such as human trafficking. ${ }^{2}$

Governments including the government of Nigeria are required to address protection of vulnerable witnesses through legislation pertaining to victim assistance, focusing on psychosocial and general support measures and the use of procedural protective measures to facilitate testimony and to minimise the risk for re-traumatisation.

4.1 Witness protection at trial

The Terrorism Prevention Amendment Act, TPA (A) 2013 has introduced in Section 34 (1), ${ }^{3}$ a legal basis for the court to take measures as it deems fit to keep the identity and address of the witness or person secret in order to protect witnesses at risk, where it is satisfied that the life of the person or witness is in danger. ${ }^{4}$

The measures which the court may take under this section may include the following-

a. hold the proceeding at a place to be decided by the court;

b. avoid physical recognition of the witness;

c. avoid mention of the real name and address of the witness or person in its orders, judgments or records of the case, which are accessible to the public; or

d. issue a direction for ensuring that the identity and address of the witness or person is not disclosed;

e. make it easier for the witness to testify;

f. undertake the proceeding in camera in order to protect the identity and location of witnesses and other persons.

g. the use of a folding Screen or Protected Panel where the witness is screened from the accused and the public in general but not from the judge and counsel.

h. guarantee the personal safety of the witness;

i. the use of Voice Distortion Technology. ${ }^{5}$

j. use of closed Circuit Television; ${ }^{6}$ The aim is principally to decrease the level of anxiety of the witness and make it easier for him/her to testify.

The court may also decide, in the public interest and national security that -

(a) all or any of the proceedings pending before the court shall not be published in any manner; and;

(b) that such proceedings shall be adjourned and the accused persons detained pending when the Attorney-General is able to guarantee the safety of the witnesses and other persons involved in the matter.

Finally, the court may, on an application by or on behalf of the relevant law enforcement or security agency, in the interest of public safety or order, exclude from proceedings for any offence under this Act any person other than the parties and their legal representatives. ${ }^{8}$

The court can also order the measures detailed in sections $34,{ }^{9}$ where it is satisfied that the life of the person or witness is in danger. ${ }^{10}$ The question becomes whether or not the court would order such measures where there is no threat to the life of the witness, but there is a risk that the witness may suffer serious psychological damage if she has to testify without protective measures.

The Prosecutors Guidelines applicable to prosecutors of a federal offence and any prosecution at a Federal Court or Court at the Federal Capital Territory (FCT) ${ }^{11}$ provides that in addition to factors affecting the seriousness of an offence, other matters, which may arise when considering public interest requires a prosecutor not to disclose or put at risk confidential information or matters of national security.

The protective measures the Act envisages limits all public disclosure of the identity of the witness. ${ }^{12}$ There seems to be no provision made explicitly for keeping the identity of a witness secret vis-à-vis the accused. The Act explicitly states that any person other than the parties and their legal representatives can be excluded from the proceedings. ${ }^{13}$ We are aware, however, that currently in some terrorism trials, the same section is interpreted to allow the court to keep the identity of the witnesses secret from the defendants and their counsel. ${ }^{14}$

Keeping witness identities secret from the defendant is a measure that will in many cases have a considerable adverse impact on the ability of the defendant to challenge the evidence against him and therefore on the right to a fair trial. It must therefore remain an exceptional measure.

${ }^{1}$ Protocol to Prevent, Suppress and Punish Trafficking in Persons, especially Women and Children, protocol to the UNCTOC. ${ }^{2}$ The United Nations Guidelines on Justice in Matters involving Child Victims and Witnesses of Crime, adopted by ECOSOC in 2005 , offer a general framework with a focus on an interdisciplinary approach towards protection of children in justice mechanisms. The UNODC 'Toolkit to Combat Trafficking in Persons' includes information and guidance on the support and protection of victims of trafficking, including victims of gender-based violence. The UN 'Good Practices for the protection of witnesses in criminal proceedings involving organized crime' very briefly mentions measures to support witnesses.

3 TPA (A) Act 2013, available on https://ctc.gov.ng/wp-content/uploads/2020/03/TERRORISM-PREVENTIONAMENDMENT-ACT-2013.pdf, accessed on $19^{\text {th }}$ July, 2021.

${ }^{4}$ Ibid.

${ }^{5}$ Also known as Voice processing Technology, this is a system where with the aid of technology, voice can be altered and the aim is to ensure confidentiality of the identity of the witness. See Ryohei Nakatsu and Yoshitake Suzuki, 'What Does VoiceProcessing Technology Support Today?' available on https://www.nap.edu/read/2308/chapter/29, accessed on 19 ${ }^{\text {th }}$ July, 2021.

${ }^{6}$ This is where the witness testifies from a room adjacent to the courtroom. The room is connected to the courtroom through closed circuit television and an audio system. This is often resorted to when child witness is testifying.

${ }^{7}$ TPA (A) Act 2013, section 34(3).

${ }^{8}$ Ibid, section 34 .

9 TPA (A) Act 2013.

${ }^{10}$ Ibid, section 34(1)

${ }^{11}$ Issued by the Attorney General of the Federation and Minister of Justice on 12th September 2013. See Federal Capital Territory Courts (Sentencing Guidelines) Practice Direction, 2016, available on https://www.unodc.org/documents/nigeria/publications/Anti-Corruption-Project-

Nigeria/Federal Capital Territory_Courts_Sentencing_Guidelines_2016. Final.pdf, accessed on 19 $9^{\text {th }}$ July, 2021.

12 TPA (A) Act 2013, Section 34.

${ }^{13}$ Ibid, Section 34(4).

${ }^{14}$ As revealed in some cases cited later on in this paper. 


\section{W.2 Witness protection during the investigation and pre-trial stages}

Effective protection of witnesses will in many cases require measures to be taken from the start of the investigation, even when a witness first enters into contact with the investigators, and throughout the pre-trial process. Witnesses may also require protection following their testimony at trial. This requires a legal framework, adequate resources and trained witness protection professionals. Such a comprehensive Witness Protection Programme has not been well developed in Nigeria presently.

4.3 Fundamental principles to assure psychological protection of women victims and witnesses

Aside from the need for a strong legal framework there are a number of important principles that need to be adhered to in order to assure psychological protection of women victims and witnesses: ${ }^{2}$ these will include-

a. Focusing on "no-harm" and increasing control and empowerment

All measures taken to protect and support women witnesses and victims should contribute to the implementation of a no-harm principle. Women should not suffer any psychological or physical harm, re-traumatization or suffering as a consequence of their involvement in the justice process. Cooperation with the witness, including support and protection, should not be started if the required follow up cannot be provided.

b. Early determination of vulnerability and follow up throughout involvement

An early determination of the level of vulnerability and the capacities of female witness is critical in order to provide adequate support and protection throughout their involvement with the justice process.

c. Confidentiality and informed consent

Confidentiality is among the first and most critical tools for witness protection. Aside from its importance to minimize the physical risk to witnesses, it is also a key condition to ensure psychological protection of vulnerable witnesses. In the case children being interviewed and/or otherwise involved in a justice mechanism, their legal guardian needs to provide informed consent. However, children's' right to participation should also be taken into consideration in the process of informed consent. Accordingly, the Child right convention provides that:

'Children have the right to express their views, opinions and beliefs freely, in their own words, and to contribute especially to decisions affecting their life, including those taken in a judicial process, and have those views taken in consideration, according to their ability, age, intellectual maturity and evolving capacities.

d. Staffing requirements and training

It is important for all staff dealing with vulnerable witnesses to have sufficient understanding of how to deal with them. Investigators need to receive training on interviewing techniques, especially of victims of sexual and other forms of gender-based violence and child witnesses. ${ }^{4}$ Staffs dealing with support and protection of vulnerable witnesses need to understand the concept of vulnerability and should be trained to be sensitive for and respond to these witnesses' needs, recognize their capacities and contain common challenges that may arise while handling the witnesses. ${ }^{5}$

e. Protection measures at pre-investigation phase

A baseline assessment needs to include extensive information about specific vulnerabilities of potential witnesses. This is particularly the case with conflict-related sexual violence. It is important to assess the impact the crimes had on these groups of victims, in particular the social impact. For example, after mass abductions, rapes, forced marriages and forced pregnancies, sexual violence victims may face social rejection and stigma.

4.3.1 Summary

The goal of all witness protection rests on the following principles:

i. Threat and risk assessment;

ii. Best interests of witnesses;

iii. Proportionality;

iv. Fully informed consent of the witness; and

v. Clear boundaries of qualification for protective measures. ${ }^{6}$

Normal practices for protection of witnesses also generally include the following risk mitigation principles:

i. Confidentiality of witnesses;

ii. Prevention of threat or harm to witnesses; and

iii. Deterrence of threats, reprisal, or victimization by those against whom they are speaking out.

Women who have been associated with Boko Haram may feel unable to cooperate with investigations for fear of reprisal from Boko Haram and the social stigma of being associated with the organization. Where witnesses feel that they are unable to be properly protected, they should not be punished for refusal to testify. Short term security gains should not be made at the expense of the rights of female witnesses ${ }^{1}$.

${ }^{1}$ For instance, the Witness Protection Programme Bill in Nigeria is yet to be passed by the National Assembly since 2012. The closest legislation on witness protection would be the Anti - Torture Act 2017. This law provides for the protection of the victim, witnesses and persons reporting torture. By the provisions of section 17 of this Act, it is the responsibility of the State to ensure that any person including the complainant; witnesses; or person making a complaint, whether the victim or not, is protected against all manner of ill treatment or intimidation.

${ }^{2}$ Fatima Waziri-Azi, Legal Framework of Witness Protection Measures during Criminal Trial in Nigeria and Emerging Practices, n 7, ibid.

${ }^{3}$ Article 12(2) of the Child Right Convention, available on https://www.unicef.org/child-rights-convention/convention-text, accessed on $20^{\text {th }}$ July, 2021.

${ }^{4}$ United Nations Office On Drugs And Crime (UNODC) Training Programme on the Treatment of Child Victims and Child Witnesses of Crime for Law Enforcement Officials, available on https://www.unodc.org/documents/justice-and-prisonreform/Training_Programme on the Treatment of Child Victims and Child Witnesses of Crime -

Law Enforcement.pdf, accessed on $20^{\text {th }}$ July, 2021.

${ }^{5}$ Ibid.

${ }^{6}$ See United Nations Office on Human Rights High commission (OHCHR): Protection of victims, witnesses and other cooperating persons Victims, Witnesses and Other Cooperating Persons, ibid. 
4.4 Ensuring protection of female witnesses to acts of terror

There are certain special guidelines for protection of vulnerable witnesses. These special principles for vulnerable witness protection include:

i. An emphasis on prevention of harm to witnesses;

ii. Increasing witness control and empowerment throughout the process;

iii. Early determination of and protection for vulnerable witnesses; and

iv. An emphasis on full consent and confidentiality of the witness.

\section{Conclusion/Recommendation}

\section{$5.1 \quad$ Conclusion}

In complex and organised crime such as terrorism, human trafficking and their likes, government should guarantee the protection of crucial witnesses. This is particularly very important in cases involving powerful individuals with links to influential networks as they can threaten, intimidate or kill these witnesses or promise them a reward to distort the evidence to be given. Under these circumstances, witnesses and their family members can be relocated and given a means of livelihood. In extreme circumstances plastic surgery could be performed on a witness in order for members of the gang not to recognise them.

Since women are more likely to be victims of terror as well as witnesses, they are likely to be subject to reprisals or stigma from the community for any association with terrorist organizations such as Boko Haram. Therefore, protection of these vulnerable witnesses is particularly important. Such protection must include not only physical safety but also access to psychological help will provide a more holistic protection.

\subsection{Recommendation}

Effective investigation and prosecution of crime is not possible without testimonies of persons who witnessed the crime either as victims or as members of the gang. Making full use of such testimonies or evidence poses a threat to the victims and witnesses and may obstruct criminal justice system, unless there is an effective witness protection mechanism in place which would protect the witness from harm or threat. Where the prosecutor has no other additional evidence to adduce in order to sustain a conviction, then the state must do everything in its capacity to protect witnesses who are to testify before the court. A comprehensive witness protection program will take such action as may be necessary and reasonable to protect the safety and welfare of a witness at risk which includes: physical and armed protection, proper arrangement necessary to allow the witness to establish a new identity, providing and relocating the witness to a new accommodation as well as reasonable financial assistance for transportation and settling into the new environment. Adequate actions should be taken during criminal proceedings to provide protective measures for vulnerable witnesses and victims and this would involve adequate funding of the judicial officers. It is one thing for procedural laws to provide for these measures and it is another thing to actualize the measures that have been provided for. As such, adequate funding should be provided and such funding should be monitored for effective utilization.

Again, Judges have the discretion to apply whatever measures they believe would be well suited in a particular case and should exercise that discretion effectively.

With the aid of evolving technology we can begin to move away from human based evidence to investigations using surveillance like CCTV cameras around crime scenes. This technique will uncover the exact crime locations like in the case of the Sambisa forest which led to the apprehension of the members of Boko Haram. Proper handling of the forensic evidence of materials recovered from the crime scenes wil also be helpful to corroborate evidence.

References:

United Nations Office on Drugs and Crime (UNODC) Handbook on effective prosecution responses to violence against women and girls, available on http://www.unodc.org/documents/justice-and-prisonreform/Handbook on effective prosecution responses to violence against women and girls.pdf.

UNODC Victim Assistance and Witness Protection, available on https:/www.unodc.org/unodc/en/organized-crime/witness-protection.html.

Report on Witness Protection (Best Practice Survey); Adopted by Committee PC-CO at its 3rd plenary meeting (Strasbourg, 15 - 17 February 1999) at pg. 11-12. https:/www.coe.int/t/dg1/legalcooperation/economiccrime/organisedcrime/BestPractice1E.pdf, accessed on 18th July, 2021.

UNODC (2008) Good practices for the protection of witnesses in criminal proceedings involving organized crime, 19. Available on www.unodc.org/documents/southeastasiaandpacific//Publications/Projects/indonesia/Good_practices for the protection of witnesses in criminal proceedings involving organized crime.pdf.

Physical and electronic surveillance, E4J University Module Series: Organized Crime, Module 8: Law Enforcement Tools and Cooperation, available on https://www.unodc.org/e4j/en/organized-crime/module-8/key-issues/special-investigative-techniques/physical-andelectronic-surveillance.html, accessed on 18th July, 2021.

Fatima Waziri-Azi, Legal Framework of Witness Protection Measures during Criminal Trial in Nigeria and Emerging Practices, European Journal of Research in Social Sciences Vol. 7 No. 1, 2019 ISSN 2056-5429 Progressive Academic Publishing, www.idpublications.org

The Office of the United Nations High Commissioner for Human Rights, commonly known as the Office of the High Commissioner for Human Rights (OHCHR) tool on Witness and Victim Protection, https://www.ohchr.org/Documents/Publications/Chapter1456pp.pdf.

Excerpt from the speech of the former secretary of the United Nations during the United Nations Secretary-General's Symposium on Supporting Victims of Terrorism, 9 September, 2008 quoted in The Criminal Justice Response to support Victims of Acts of Terrorism available on http://www.un.org/en/terrorism/ctitf/pdfs/victims_rights_e-book- accessed on 18th July, 2021.

Welsh, Brandon C., and David P. Farrington. "Effects of Closed-Circuit Television on Crime." The Annals of the American Academy of Political and Social Science, vol. 587, 2003, pp. 110-135. JSTOR, www.jstor.org/stable/1049950.

Eniko F, The rising importance on the protection of witness https://www.caim.info.revue-internationale-de-droit.

George, B. J. "Victim and Witness Protection," Contemporary Federal Criminal Practice, (1984) Vol. 2, p. 683.

${ }^{1}$ UNODC: Gender mainstreaming in the work of UNODC

http://www.un.org/womenwatch/directory/docs/UNODC-GuidanceNote-GenderMainstreaming.pdf 
Graham, M.H, Witness Intimidation-The Law’s Response, Quorum Books, Division of Greenwood Press, Inc, (1985). P. 330

United Nations Declaration (1985), also known as Declaration of Basic Principles of Justice For Victims of Crime and Abuse of Power 'Understanding the concept of victims of crime and a short history of victimology', E4J University Module Series: Crime Prevention and Criminal Justice Module 11: Access to Justice for Victims, available on https://www.unodc.org/e4j/en/crime-preventioncriminal-justice/module-11/key-issues/1--understanding-the-concept-of-victims-of-crime.html.

Basic Principles and Guidelines on the Right to a Remedy and Reparation for Victims of Gross Violations of International Human Rights Law and Serious Violations of International Humanitarian Law Adopted and proclaimed by General Assembly resolution 60/147 of 16 December 2005, available on https://www.ohchr.org/en/professionalinterest/pages/remedyandreparation.aspx.

International Criminal Court: "Protocol on the vulnerability assessment and support procedure used to facilitate the testimony of vulnerable witnesses" (ICC-01/05-01/08-974-Anx2), available on https://www.icc-cpi.int/RelatedRecords/CR2014 10208.PDF,

The Protocol to Prevent, Suppress and Punish Trafficking in Persons, Especially Women and Children, supplementing the United Nations Convention against Transnational Organized Crime (General Assembly resolution 55/25, annex II, articles 6 and 7) and the Protocol against the Smuggling of Migrants by Land, Sea and Air, supplementing the United Nations Convention against Transnational Organized Crime (Assembly resolution 55/25, annex III, articles 5 and 16). Available on https://www.unodc.org/unodc/en/organizedcrime/witness-protection.html at page 21, accessed 23rd June 2020.

Terrorism (Prevention) (Amendment) Act 2013.

Terrorism (Prevention) (Amendment) Act 2013, Section 34 (2).

Administration of Criminal Justice Act (ACJA) 2015, Section 232.

Federal

Capital Territory Courts (Sentencing Guidelines) Practice Direction, 2016, available on https://www.unodc.org/documents/nigeria/publications/Anti-Corruption-Project

Nigeria/Federal Capital Territory Courts Sentencing Guidelines 2016. Final.pdf, accessed on 19th July, 2021.

The Child Right Convention, available on https://www.unicef.org/child-rights-convention/convention-text, accessed on 20 th July, 2021.

United Nations Office on Drugs and Crime (UNODC) Training Programme on the Treatment of Child Victims and Child Witnesses of Crime for Law Enforcement Officials, available on https://www.unodc.org/documents/justice-and-prisonreform/Training_Programme_on_the_Treatment_of_Child_Victims_and_Child_Witnesses_of_Crime_-_Law_Enforcement.pdf, accessed on 20th July, 2021. 